\title{
DISTRIBUTION OF ENTOCYTHERIDAE (CRUSTACEA: OSTRACODA) IN THE NORTHERN PRAIRIES OF NORTH AMERICA AND REPORTS OF OPPORTUNISTIC CLITELLATE ANNELIDS ON CRAYFISH HOSTS
}

\author{
Bronwyn W. Williams ${ }^{1,3}$, Kathryn L. Williams ${ }^{1}$, Stuart R. Gelder ${ }^{2}$, and Heather C. Proctor ${ }^{1}$
}

\begin{abstract}
Northern cravfish, Orconectes virilis (Hagen, 1870), were collected from 89 sites across Alberta, Saskatchewan, Manitoba, Montana, North Dakota, and Minnesota. The entocytherid ostracod Thermastrocythere riojai (Hoff, 1943) was found on $O$. virilis at 45 of the 89 sites, distributed primarily in the eastern and southern portion of the study area. These observations of $T$. riojai greatly extend the known range of the species. The widespread distribution of $T$. riojai suggests that the dearth of entocytherid records from other parts of Canada is a result of nontargeted sampling rather than true absence. In addition, we report on observations of 3 noteworthy associations of oligochaetes with their crayfish hosts.

REsumen.-Se colectaron especímenes del acocil Orconectes virilis (Hagen, 1870) en 89 sitios a lo largo de Alberta, Saskatchewan, Manitoba, Montana, North Dakota y Minnesota. Encontramos el ostracódo entocitérido Thermastrocythere riojai (Hoff, 1943) en O. virilis en 45 de los 89 sitios, distribuidos principalmente en la parte sur y la parte este del área de estudio. Estas observaciones de T. riojai amplían considerablemente el área de distribución conocida de esta especie. La distribución extensa de T. riojai sugiere que la escasez de registros de entocitéridos en otras partes de Canadá es el resultado del muestreo inespecífico y no de una ausencia verdadera. Además, reportamos observaciones de 3 asociaciones sobresalientes entre los oligoquetos y los acociles huéspedes.
\end{abstract}

Entocytheridae is a family of ostracods that are obligate ectosymbionts of other crustaceans ranging across southern central Europe, southern India, Australasia, and North America (Hart and Hart 1974). Two entocytherid subfamilies have been described from North America: (1) Entocytherinae, commensal on freshwater crayfishes of the families Astacidae and Cambaridae and on one species of freshwater crab, Pseudothelphusa veracruzana Rodriquez and Smalley, 1970; and (2) Sphaeromicolinae, commensal on freshwater isopods of the family Cirolanidae (Hart and Hart 1974). The known distribution of entocytherids in North America extends from Cuba and Mexico north to a boundary that approximates to the United States-Canada border (reviewed in Hart and Hart 1974). Despite widespread occurrence of several potential host crayfish species (e.g., Crocker and Barr 1968, Taylor et al. 1996, Hamr 1998, Hamr 2002 , Williams et al. 2011), few published records of entocytherids exist in Canada. The description of Entocythere insignipes (Sars, 1926) was the sole report from the country until 1970, when Thermastrocythere riojai (Hoff, 1943) was found on crayfish collected in the Swan River near the town of Swan River in western Manitoba
(Delorme 1970d, Hart and Hart 1974). No further contributions to the knowledge of entocytherid ostracods in Canada have been made since.

Similarly, reports of entocytherids are lacking from large areas of the northern Great Plains of the United States, including Montana and North Dakota. Representatives of another group of crayfish ectosymbionts, branchiobdellidans or crayfish worms, were recently discovered in the Prairie Provinces of Canada (Williams et al. 2009) and in Montana and North Dakota (B.W. Williams unpublished observation). The wide distribution of these worms suggests that the prior dearth of reports was due to lack of targeted sampling. Therefore, it is likely that other crayfish-associated organisms, including entocytherid ostracods, have also gone unnoticed across the region.

The aim of the current study is to document the distribution of entocytherid ostracods associated with crayfish hosts in the Prairie Provinces of Canada, with additional reports from Montana, North Dakota, and Minnesota. We also provide information on incidental, yet notable, observations of 3 additional taxa associated with crayfish hosts.

${ }^{1}$ Department of Biological Sciences, University of Alberta, Edmonton, Alberta T6G 2E9, Canada.

${ }^{2}$ Department of Science and Math, University of Maine at Presque Isle, 181 Main Street, Presque Isle, ME 04769

3E-mail: bwwillia@ualberta.ca 


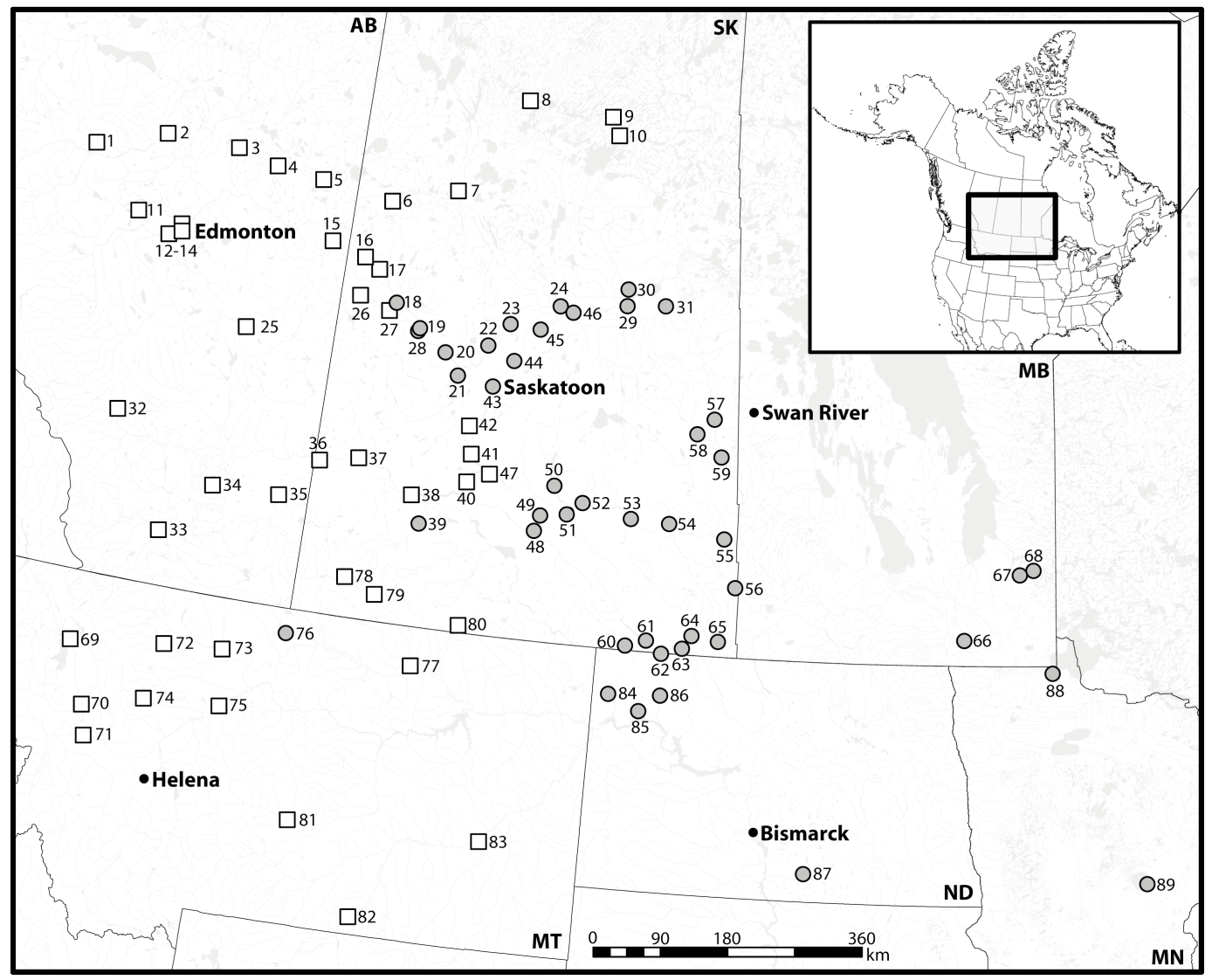

Fig. 1. Orconectes virilis (Hagen, 1870) sampling sites in the northern prairies of North America (Alberta, AB; Saskatchewan, SK; Manitoba, MB; Montana, MT; North Dakota, ND; Minnesota, MN) showing detection (shaded circles) and nondetection (open squares) of the entocytherid ostracod Thermastrocythere riojai (Hoff, 1943). Inset map delineates the study area in North America. Site numbers correspond to information provided in the appendix.

Northern crayfish, Orconectes virilis (Hagen, 1870), were collected as part of an ongoing population genetics study. A subset of specimens previously examined for branchiobdellidans (Williams et al. 2009; Appendix) were reexamined for entocytherid ostracods. Additional crayfish were collected by hand, by kick-netting, or in Gee minnow traps (Wildlife Supply Company, Buffalo, NY) deployed for up to 24 hours. The size of entrance holes in the minnow traps was increased to approximately $60 \mathrm{~mm}$ to allow access by adult crayfish. Crayfish were preserved individually in containers of $95 \%$ ethanol.

We examined a total of 1376 crayfish collected from 89 sites across Alberta, Saskatchewan, Manitoba, Montana, North Dakota, and Minnesota between August 2006 and October 2010 (Fig. 1, Appendix). The study area included portions of the Arctic, Hudson Bay, and Gulf of
Mexico ocean watersheds. We used a dissecting microscope to examine the external surface and branchial chambers of each crayfish and the debris at the bottom of sampling containers for presence of entocytherid ostracods. Entocytherids were transferred to separate containers of $95 \%$ ethanol for preservation and storage. Representative entocytherids were dehydrated in $100 \%$ ethanol, cleared in methyl salicylate, infiltrated with Canada balsam, and mounted on glass slides to museum standards. Species identification was made using the keys and information in Hart and Hart (1974). Slide mounts were deposited in the New Brunswick Museum, Saint John, New Brunswick, Canada, as catalogue numbers NBM-007156-007160.

Entocytherid ostracods were found at $50.1 \%$ (45 of 89) of surveyed sites (Fig. 1, Appendix) in Saskatchewan, Manitoba, Montana, North 
Dakota, and Minnesota. Entocytherids were attached to setae along the abdomen; around legs, maxillipeds, bases of antennae, and chelae; and under the rostrum of their crayfish hosts. Thermastrocythere riojai was the only species of entocytherid ostracod found.

During our study, we observed additional organisms associated with $O$. virilis. The findings of 3 of these organisms are noteworthy, as all represent previously unreported associations. An enchytraeid oligochaete was found in the gill chamber of an $O$. virilis specimen collected from Nose Creek in Calgary, Alberta (site 32; Fig. 1). Although enchytraeids are usually free-living, Lumbricillus catanensis (Drago, 1887) has been reported in the branchial chambers of the freshwater crab, Potamon fluviatilis (Herbst, 1785) (= Telphusa fluviatilis) in Italy (Gelder 1980). We also noted specimens of the oligochaete Chaetogaster limnaei Baer, 1827, on the carapace of 3 O. virilis collected in Long Creek, southern Saskatchewan (site 60; Fig. 1). Although C. limnaei is known worldwide as an ectocommensal of freshwater molluscs, primarily in the gill chamber of gastropods (Gelder 1980), it has not previously been reported in association with crayfish. Lastly, we recovered additional small oligochaetes from the carapace of $O$. virilis from Long Creek. Although many of the small oligochaetes fragmented during preservation, we identified a subset as Nais sp., either Nais alpina Sperber, 1948 or Nais simplex Piguet, 1906. Nais sp. and other naidids have been observed on freshwater ectoprocts, which Sperber (1948) considered part of their normal foraging habits and which is consistent with our observations on crayfish. Both Nais species and C. limnaei have been previously reported from Canada (Brinkhurst 1986). As each of the above associations was observed only once, presence of these oligochaetes on $O$. virilis in our collection is unlikely to reflect a stable symbiosis. Conversely, our findings are likely a result of natural, random wanderings of the host and oligochaetes over the substratum.

Prior to this study, T. riojai was known in Canada only from a single site in western Manitoba (Delorme 1970d, Hart and Hart 1974). Our survey greatly extends the reported distribution of $T$. riojai westward into central and western Saskatchewan. We also provide new records of the species in areas of Montana, North Dakota, eastern Manitoba, and northern Minnesota. The species is now known to range from eastern
Texas and Louisiana north through the northern Great Plains and western Great Lakes states, and into the eastern and central Prairie Provinces (Hart and Hart 1974). Detections of T. rio$j a i$ at sites on the Winnipeg River in Manitoba (sites 67,68) and Lake of the Woods in Minnesota (site 88) indicate that the species may also be present in adjoining waterways of southwestern Ontario.

It is important to note that the crayfish from Swan River harboring T. riojai had been identified as the rusty crayfish, Orconectes rusticus (Girard, 1852) (Delorme 1970d). Originating from areas of north central North America (Tennessee, Kentucky, Indiana, Ohio, Michigan, and southern Ontario; Hobbs 1974), O. rusticus is thought to have been only recently introduced to southeastern Manitoba through its use as live bait; the first confirmed report of the species in the province was from Falcon Lake in 2007 (Lowdon 2009). As the lack of known voucher specimens precluded species verification of the original collection, we suggest that the crayfish collected from Swan River were likely $O$. virilis. Orconectes virilis is the only species found throughout much of the Prairie Provinces (Williams et al. 2011), including a sampling site in the current study (site 57 on the Swan River, Saskatchewan) approximately $50 \mathrm{~km}$ upstream from the town of Swan River, Manitoba. The calico crayfish, Orconectes immunis (Hagen, 1870), unsampled in this study, is also found in Manitoba but is restricted to the southeastern portion of the province in the Red River drainage and in 2 isolated areas in the Winnipeg River near the Ontario border.

Although we did not sample in western Manitoba, the distribution of T. riojai appears to be contiguous along the rivers of Saskatchewan and Manitoba (Fig. 1). On the basis of our collections and previous records summarized in Hart and Hart (1974), the general northern distribution likely includes the Red and Assiniboine River systems flowing into southern Hudson Bay, the Upper Great Lakes region draining to the Atlantic Ocean, and the Missouri and Upper Mississippi River systems flowing south toward the Gulf of Mexico. The western edge of the observed T. riojai distribution was inconsistent across sampled waterways relative to longitude. These differing observed range limits could result from incomplete sampling, such as the lack of collections 
made along the Missouri River in eastern Montana and western North Dakota. However, particularly in rivers that were systematically sampled in this study (e.g., the North Saskatchewan and South Saskatchewan rivers), variation in range boundaries suggests differing barriers, such as physical (e.g., dams) or environmental barriers (e.g., tolerance limits).

The westernmost collection of $T$. riojai was from Fresno Reservoir on the Milk River in northern Montana (site $76,48.685^{\circ} \mathrm{N}, 100.008^{\circ} \mathrm{W}$; Fig. 1). However, this collection appears to be isolated and distant from the nearest collections of $T$. riojai to the north and east. No entocytherids were found elsewhere in Montana, including a second site on the Milk River (site 77; Fig. 1) and locations sampled in southern Saskatchewan in streams or rivers that drain into the Milk River (e.g., sites 78-80; Fig. 1). An identical distribution pattern was observed for the branchiobdellidan Cambarincola vitreus Ellis, 1919, which was found on O. virilis in Fresno Reservoir but on no other crayfish examined from Montana (B.W. Williams unpublished observation). Although nondetection does not necessarily correspond to true absence, the isolated observations of T. riojai and C. vitreus in Fresno Reservoir suggest an introduction of the $O$. virilis host from an area where both symbionts are sympatric (for distributions see Hart and Hart 1974, Gelder et al. 2002, Williams et al. 2009).

Orconectes virilis has been expanding its range westward in Montana and in the Prairie Provinces of Canada due to an apparent combination of natural dispersal and human-mediated introduction (Williams et al. 2011). In some cases, such as with $O$. virilis from the Fresno Reservoir, symbiont presence might be used to indicate likely crayfish introductions. A second host introduction might explain an apparent isolated collection of $T$. riojai in Swift Current Creek, Saskatchewan (site 39; Fig. 1). Two major dams, the Qu'Appelle River Dam and the Gardiner Dam, separate the Swift Current Creek collection from both nearest observed collections of $T$. riojai (site 43 on the South Saskatchewan River and site 49 on the Qu'Appelle River).

At the majority of sites where $T$. riojai was observed, the species was common and found on the majority of crayfish examined. In contrast, entocytherids were rare at the western edge of the observed range, suggestive of environmental tolerances or few founders at a leading edge of a range expansion. For example, a total of $5 T$. riojai were found among 21 crayfish examined from site 18 (Fig. 1). In contrast, $T$. riojai were numerous $(>5$ per crayfish) in the 2 isolated populations observed in Fresno Reservoir (site 76) and Swift Current Creek (site 39), despite the examination of only $2 \mathrm{O}$. virilis hosts from the former site.

Delorme's (1970a, 1970b, 1970c, 1970d) 4-part review of freshwater ostracods of Canada included 84 species from 8 families but only a single species of entocytherid, T. riojai, from Swan River, Manitoba. The earliest recorded entocytherid from Canada, Cytherites insignipes Sars, 1926, was a new species description based on examination of 3 female specimens; however, collector, locality (other than "Canada"), date of collection, host, and male morphology were all unknown. Hoff (1944) reassigned C. insignipes to the genus Entocythere, but due to the lack of taxonomically distinguishing male morphological characters, the species is currently considered incertae sedis (Hart 1962).

Several entocytherid species are reported from areas immediately south of the United States-Canada border, including Uncinocythere occidentalis (Kozloff and Whitman, 1954) and Uncinocythere columbia (Dobbin, 1941) in northern Washington; Uncinocythere stubbsi Hobbs and Walton, 1966, and T. riojai in the Upper Great Lakes states; and Donnaldsoncythere scalis Hobbs and Walton, 1963, in upper New England (ranges summarized in Hart and Hart 1974). Several potential crayfish hosts are found throughout southern Canada as extensions of known distributions in the United States. Therefore, it is inevitable that additional records and range extensions of entocytherid ostracods will appear as researchers begin targeted examination of crayfishes in Canada.

\section{Author Contributions}

BWW made the majority of the field collections across Alberta and Saskatchewan, Canada, identified the crayfish and entocytherid species, and prepared the manuscript. KLW assisted with field collection and laboratory sampling of the entocytherids. SRG identified the additional oligochaetes and assisted with manuscript preparation. HCP provided laboratory space and resources. 


\section{ACKNOWLEDGMENTS}

We thank Susan Adams (USDA Forest Service), Cody Nagel, Mike Ruggles, Mike Backes, Bill Gardner, and Dave Yerk (Montana Fish, Wildlife and Parks), Fred Ryckman and Lynn Schlueter (North Dakota Game and Fish Department), Melissa Drake and Patrick Schmalz (Minnesota Department of Natural Resources), Lane Graham and Terry Galloway (University of Manitoba), Terry Clayton (Alberta Sustainable Resource Development), and Iain Phillips (Saskatchewan Watershed Authority) for assisting with sample collection. Funding for field collection of crayfish was provided to BWW through the Alberta Conservation Association Grants in Biodiversity, and laboratory work was funded by a Natural Sciences and Engineering Research Council of Canada (NSERC) Discovery Grant to HCP.

\section{Literature Cited}

BRinkhurst, R.O. 1986. Guide to the freshwater aquatic microdrile Oligochaetes of North America. Canadian Special Publications of Fisheries and Aquatic Sciences 84, Department of Fisheries and Oceans, Ottawa, Ontario, Canada.

Crocker, D.W., AND D.W. Barr. 1968. Handbook of the crayfishes of Ontario. University of Toronto Press, Toronto, Ontario, Canada.

Delorme, L.D. 1970a. Freshwater ostracodes of Canada. Part I. Subfamily Cypridinae. Canadian Journal of Zoology 48:153-168.

1970b. Freshwater ostracodes of Canada. Part II. Subfamily Cypridopsinae and Herpetocypridinae, and family Cyclocyprididae. Canadian Journal of Zoology 48:253-266.

1970c. Freshwater ostracodes of Canada. Part III. Family Candonidae. Canadian Journal of Zoology 48: 1099-1127.

. 1970d. Freshwater ostracodes of Canada. Part IV. Families Ilyocyprididae, Notodromadidae, Darwinulidae, Cytherideidae, and Entocytheridae. Canadian Journal of Zoology 48:1251-1259.
GELDER, S.R. 1980. A review of the symbiotic Oligochaeta (Annelida). Zoologischer Anzeiger 204:69-81.

Gelder, S.R., N.L. Gagnon, And K. Nelson. 2002. Taxonomic considerations and distribution of the Branchiobdellida (Annelia: Clitellata) on the North American continent. Northeastern Naturalist 9:451-468.

Hamr, P. 1998. Conservation status of Canadian freshwater crayfishes. World Wildlife Fund Canada and the Canadian Nature Federation, Toronto, Ontario, Canada. 2002. Orconectes. Pages 585-608 in D.M. Holdich, editor, Biology of freshwater crayfish. Blackwell Scientific Press, Oxford.

HaRt, C.W., JR. 1962. A revision of the ostracods of the family Entocytheridae. Proceedings of the Academy of Natural Sciences of Philadelphia 114:121-147.

Hart, D.G., AND C.W. Hart JR. 1974. The ostracod family Entocytheridae. Monograph 18. Academy of Natural Sciences of Philadelphia, Philadelphia, PA.

HobBs, H.H., JR. 1974. A checklist of the North and Middle American crayfishes (Decapoda: Astacidae and Cambaridae). Smithsonian Contributions to Zoology 166: $1-161$.

Hoff, C.C. 1944. New American species of the ostracod genus Entocythere. American Midland Naturalist 32: 327-357.

LowDON, M. 2009. Rusty crayfish survey Falcon Lake 2009. Prepared for Manitoba Water Stewardship by AAE Tech Services, Inc.

SARS, G.O. 1926. Fresh-water Ostracoda from Canada and Alaska. Report, Canadian Arctic Expedition, 19131918. 7:1-32, 5 plates.

Sperber, C. 1948. A taxonomic study of the Naididae. Zoologiska Bidrag från Uppsala 28:1-296.

Taylor, C.A., M.L. Warren, J.F. FitzPatrick JR., H.H. Hobbs III, R.F. Jezerinac, W.L. Pflieger, and H.W. Robison. 1996. Conservation status of crayfishes of the United States and Canada. Fisheries 21:25-38.

Williams, B.W., S.R. Gelder, and H. Proctor. 2009. Distribution and first reports of Branchiobdellida (Annelida: Clitellata) on crayfish in the Prairie Provinces of Canada. Western North American Naturalist 69:119-124.

Williams, B.W., H.C. Proctor, and T. Clayton. 2011. Range extension of the northern crayfish, Orconectes virilis (Decapoda, Cambaridae), in the western Prairie Provinces of Canada. Crustaceana 84:451-460.

Received 15 October 2010 Accepted 23 February 2011

See Appendix on pages 281-282. 
APPENDIX. Detection (+) or nondetection (-) of the entocytherid ostracod Thermastrocythere riojai (Hoff, 1943) on Orconectes virilis (Hagen, 1870) collected across the northern prairies region, with information on sample location (latitude and longitude, NAD83) and number of hosts examined ( $N$ hosts). Site numbers correspond to locations in Figure 1.

\begin{tabular}{|c|c|c|c|c|c|}
\hline Site & Waterbody & Latitude $\left({ }^{\circ} \mathrm{N}\right)$ & Longitude $\left({ }^{\circ} \mathrm{W}\right)$ & T. riojai & $N$ hosts \\
\hline 1 & McLeod Lake & 54.293 & 115.651 & - & 29 \\
\hline 2 & Beyette Lake & 54.592 & 114.199 & - & 15 \\
\hline 3 & Amisk Lake & 54.604 & 112.647 & - & 22 \\
\hline 4 & Amisk River & 54.461 & 111.772 & - & 23 \\
\hline 5 & Beaver River & 54.389 & 110.755 & - & 21 \\
\hline 6 & Beaver River & 54.260 & 109.221 & - & 26 \\
\hline 7 & Beaver River & 54.510 & 107.868 & - & 12 \\
\hline 8 & Churchill River & 55.733 & 106.565 & - & 1 \\
\hline 9 & Churchill River & 55.643 & 104.734 & - & 30 \\
\hline 10 & Churchill River & 55.418 & 104.561 & - & 28 \\
\hline 11 & East Pit Lake & 53.584 & 114.464 & - & 5 \\
\hline 12 & North Saskatchewan River & 53.370 & 113.751 & - & 16 \\
\hline 13 & Bearspaw Lake & 53.443 & 113.505 & - & 26 \\
\hline 14 & North Saskatchewan River & 53.502 & 113.561 & - & 28 \\
\hline 15 & North Saskatchewan River & 53.659 & 110.337 & - & $6^{\mathrm{a}}$ \\
\hline 16 & North Saskatchewan River & 53.523 & 109.618 & - & 19 \\
\hline 17 & North Saskatchewan River & 53.396 & 109.293 & - & 29 \\
\hline 18 & North Saskatchewan River & 53.245 & 105.433 & + & 20 \\
\hline 19 & North Saskatchewan River & 52.743 & 108.284 & + & 13 \\
\hline 20 & North Saskatchewan River & 52.491 & 107.699 & + & 19 \\
\hline 21 & Eagle Creek & 52.232 & 107.380 & + & 26 \\
\hline 22 & North Saskatchewan River & 52.646 & 106.842 & + & 18 \\
\hline 23 & North Saskatchewan River & 52.946 & 106.435 & + & 24 \\
\hline 24 & North Saskatchewan River & 53.182 & 105.162 & + & 22 \\
\hline 25 & Battle River & 52.409 & 111.810 & - & $20^{\mathrm{a}}$ \\
\hline 26 & Battle River & 53.046 & 109.601 & - & 25 \\
\hline 27 & Battle River & 52.907 & 108.949 & - & 20 \\
\hline 28 & Battle River & 52.717 & 108.310 & + & 21 \\
\hline 29 & Saskatchewan River & 53.237 & 104.464 & + & 17 \\
\hline 30 & Torch River & 53.539 & 104.069 & + & 19 \\
\hline 31 & Carrot River & 53.366 & 103.264 & + & 26 \\
\hline 32 & Nose Creek & 51.086 & 114.047 & - & 16 \\
\hline 33 & Henderson Lake & 49.688 & 112.790 & - & 24 \\
\hline 34 & Lake Newell Reservoir & 50.379 & 111.911 & - & 20 \\
\hline 35 & South Saskatchewan River & 50.399 & 110.589 & - & 13 \\
\hline 36 & South Saskatchewan River & 50.913 & 109.890 & - & 4 \\
\hline 37 & South Saskatchewan River & 51.024 & 109.134 & - & $36^{\mathrm{a}}$ \\
\hline 38 & South Saskatchewan River & 50.656 & 107.975 & - & $27^{\mathrm{a}}$ \\
\hline 39 & Swift Current Creek & 50.308 & 107.769 & + & 31 \\
\hline 40 & South Saskatchewan River & 50.905 & 106.917 & - & 22 \\
\hline 41 & South Saskatchewan River & 51.259 & 106.896 & - & 10 \\
\hline 42 & South Saskatchewan River & 51.613 & 107.008 & - & 14 \\
\hline 43 & South Saskatchewan River & 52.137 & 106.646 & + & $12^{\mathrm{a}}$ \\
\hline 44 & South Saskatchewan River & 52.491 & 106.283 & + & 25 \\
\hline 45 & South Saskatchewan River & 52.923 & 105.805 & + & 22 \\
\hline 46 & South Saskatchewan River & 53.182 & 105.162 & + & 25 \\
\hline 47 & South Saskatchewan River & 51.034 & 106.494 & - & 21 \\
\hline 48 & Moose Jaw Creek & 50.394 & 105.497 & + & 24 \\
\hline 49 & Qu’Appelle River & 50.595 & 105.411 & + & 22 \\
\hline 50 & Last Mountain Lake & 50.992 & 105.180 & + & 21 \\
\hline 51 & Qu'Appelle River & 50.630 & 105.007 & + & 12 \\
\hline 52 & Qu'Appelle River & 50.804 & 104.581 & + & 20 \\
\hline 53 & Qu'Appelle River & 50.662 & 103.603 & + & 20 \\
\hline 54 & Qu'Appelle River & 50.642 & 102.847 & + & 21 \\
\hline 55 & Qu'Appelle River & 50.499 & 101.728 & + & 10 \\
\hline 56 & Pipestone Creek & 49.886 & 101.449 & + & 28 \\
\hline 57 & Swan River & 51.998 & 102.075 & + & 21 \\
\hline 58 & Assiniboine River & 51.792 & 102.408 & + & 15 \\
\hline 59 & Assiniboine River & 51.533 & 101.877 & + & 20 \\
\hline 60 & Long Creek & 49.062 & 103.498 & + & 4 \\
\hline 61 & Rafferty Dam Reservoir & 49.145 & 103.098 & + & 25 \\
\hline
\end{tabular}


APPEndix. Continued.

\begin{tabular}{|c|c|c|c|c|c|}
\hline Site & Waterbody & Latitude $\left({ }^{\circ} \mathrm{N}\right)$ & Longitude $\left({ }^{\circ} \mathrm{W}\right)$ & T. riojai & $N$ hosts \\
\hline 62 & Short Creek Dam & 48.992 & 102.784 & + & 12 \\
\hline 63 & Souris River & 49.079 & 102.399 & + & 17 \\
\hline 64 & Moose Mountain Creek & 49.261 & 102.239 & + & 21 \\
\hline 65 & Antler River & 49.193 & 101.711 & + & 6 \\
\hline 66 & Rat River & 49.317 & 96.945 & + & 2 \\
\hline 67 & Winnipeg River & 50.160 & 95.867 & + & 1 \\
\hline 68 & Winnipeg River & 50.210 & 95.588 & + & 13 \\
\hline 69 & Echo Lake & 48.121 & 114.036 & - & 3 \\
\hline 70 & Lake Alva & 47.316 & 113.582 & - & 3 \\
\hline 71 & Clearwater River & 46.945 & 113.431 & - & 3 \\
\hline 72 & Lake Frances & 48.285 & 112.264 & - & 3 \\
\hline 73 & Tiber Reservoir & 48.342 & 111.163 & - & 3 \\
\hline 74 & Willow Creek Reservoir & 47.557 & 112.443 & - & 3 \\
\hline 75 & Missouri River & 47.627 & 111.035 & - & 4 \\
\hline 76 & Fresno Reservoir & 48.685 & 110.008 & + & 2 \\
\hline 77 & Nelson Reservoir & 48.495 & 107.546 & - & 2 \\
\hline 78 & Conglomerate Creek & 49.507 & 109.047 & - & 4 \\
\hline 79 & Frenchman River & 49.335 & 108.417 & - & 27 \\
\hline 80 & Weatherall Creek & 49.093 & 106.738 & - & 1 \\
\hline 81 & Deadmans Basin & 46.339 & 109.426 & - & 2 \\
\hline 82 & Yellowtail Dam & 45.228 & 108.072 & - & 5 \\
\hline 83 & Settling pond, Miles City & 46.387 & 105.867 & - & 2 \\
\hline 84 & Blacktail Dam & 48.433 & 103.735 & + & 3 \\
\hline 85 & Kota-Ray Dam & 48.239 & 103.143 & + & 3 \\
\hline 86 & White Earth Dam & 48.456 & 102.744 & + & 3 \\
\hline 87 & Beaver Creek & 46.297 & 99.866 & + & 7 \\
\hline 88 & Lake of the Woods & 48.899 & 95.240 & + & 3 \\
\hline 89 & Mille Lacs & 46.211 & 93.528 & + & 7 \\
\hline
\end{tabular}

aCrayfish collected for Williams et al. (2009) re-examined for presence of entocytherids. 